\title{
Evaluasi Program Manajerial Kepala Sekolah
}

\author{
Egidius Virgo \\ Magister Manajemen Pendidikan Universitas Kristen Satya Wacana \\ egidiusvirgo93@gmail.com \\ Slameto \\ Magister Manajemen Pendidikan Universitas Kristen Satya Wacana \\ slameto@staff.uksw.edu
}

\begin{abstract}
The aim of this study is to evaluate the context, input, process, and product of the Principal Managerial Program in a Salatiga Private Elementary School. This study is evaluative research using CIPP models. The data collection includes interviews, documentation studies, and observations. The data validation was technique and resource triangulation. The study results: a) the context evaluation showed the managerial program of principals in private elementary schools is indeed very much needed by school stakeholders; b) the input evaluation showed the principal managerial program has been prepared to meet stakeholder needs, but has not been supported by human resources, funding, and adequate infrastructure; c) the process evaluation showed the principal's managerial program carried out based on management functions namely: planning, organizing, supervision, and assessment. Even though it is constrained in terms of human resources, funding, and infrastructure, but the principal still can carry out a minimum managerial program, d) the product evaluation showed the Private Elementary School achieves more in the non-academic field than in the academic field, although from year to year there is a slight increase in the quality of student learning outcomes.
\end{abstract}

Keywords: CIPP, Program Evaluation, Principal's Managerial Program

\section{Article Info}

Received date: 10 Desember 2018 Revised date: 21 Desember $2018 \quad$ Accepted date: 21 Desember 2018

\section{PENDAHULUAN}

Peningkatan mutu pendidikan merupakan sasaran pembangunan di bidang pendidikan nasional. Mutu pendidikan dapat dipengaruhi oleh banyak faktor, salah satunya adalah faktor manajemen sekolah. Manajemen merupakan suatu proses perencanaan, pengorganisasian, kepemimpinan, dan pengendalian anggota organisasi serta penggunaan seluruh sumber daya organisasi lainnya demi tercapainya tujuan organisasi
(Siswanto, 2015: 2). Di sekolah fungsi manajerial ini dijalankan oleh Kepala Sekolah. Menurut Keputusan Menteri Pendidikan Nomor: 162/U/2003 tanggal 24 Oktober 2003 tentang Pedoman Penugasan Guru sebagai Kepala Sekolah, Kepala Sekolah adalah guru yang mendapatkan tugas tambahan untuk memimpin sebuah lembaga pendidikan. Sedang Wahjosumidjo (2005: 83) mendefinisikan Kepala Sekolah sebagai seorang tenaga fungsional guru yang diberi tugas untuk memimpin suatu sekolah dimana 
Kelola: Jurnal Manajemen Pendidikan, Vol. 5, No. 2, Juli-Desember 2018

diselenggarakan proses belajar mengajar, atau tempat dimana terjadi interaksi antara guru yang memberi pelajaran dan murid sebagai penerima pelajaran. Dari definisi tersebut dapat dipahami bahwa, secara sederhana pengertian Kepala Sekolah adalah seorang tenaga fungsional guru yang diberi tugas untuk memimpin suatu sekolah dimana diselenggarakan proses belajar mengajar atau tempat dimana terjadi interaksi antara guru yang memberi pelajaran dan murid yang menerima pelajaran. Dengan ini Kepala Sekolah dapat disebut sebagai pemimpin di satuan pendidikan yang tugasnya menjalankan menajemen satuan pendidikan yang dipimpinnya. Di tingkat operasional, Kepala Sekolah adalah orang yang berposisi di garis terdepan yang mengkoordinasikan upaya dalam meningkatkan pembelajaran bermutu. Kepala Sekolah diangkat untuk menduduki jabatan bertanggung jawab mengkoordinasi kan upaya bersama mencapai tujuan pendidikan di tingkat sekolah. Tentu saja Kepala Sekolah bukan satusatunya yang bertanggung jawab penuh terhadap suatu sekolah, karena masih banyak faktor lain yang perlu diperhitungkan. Selain Kepala Sekolah, ada guru yang dipandang sebagai faktor kunci yang berhadapan langsung dengan para peserta didik dan faktor lain seperti lingkungan yang mempengaruhi proses pembelajaran. Namun Kepala Sekolah memiliki peran yang berpengaruh terhadap jalannya sistem yang ada di sekolah.

Kepala Sekolah adalah salah satu komponen pendidikan yang berperan dalam meningkatkan kualitas pendidikan. Kepala Sekolah merupakan penanggung jawab atas penyelenggaraan proses pendidikan, administrasi sekolah, pembinaan tenaga pendidikan lainnya, pendayagunaan serta pemeliharaan sarana dan prasarana juga sebagai supervisor pada sekolah yang dipimpinnya. Jika dilihat dari syarat guru untuk menjadi Kepala Sekolah, Kepala Sekolah bisa dikatakan sebagai jenjang karier dari jabatan fungsional guru. Apabila seorang guru memiliki kompetensi sebagai Kepala Sekolah dan telah memenuhi persyaratan atau tes tertentu maka guru tersebut dapat memperoleh jabatan Kepala Sekolah (Mulyasa, 2007: 24).

Kepala Sekolah bertanggungjawab atas manajemen pendidikan secara mikro, yang secara langsung berkaitan dengan proses pembelajaran. Pada dasarnya pengelolaan sekolah menjadi tanggung jawab Kepala Sekolah dan guru. Namun demikian dalam mencapai keberhasilan pengelolaan sekolah peran serta dari para orang tua dan siswa, juga turut mendukung keberhasilan itu. Di samping itu pencapaian keberhasilan, pengelolaan tersebut harus didukung oleh sikap pola dan kemampuan Kepala Sekolah dalam memimpin lembaga pendidikan yang menjadi tanggung jawabnya. Kepemimpinan seorang Kepala Sekolah diharapkan dapat menciptakan kondisi yang memungkinkan bagi lahirnya iklim kerja dan hubungan antar manusia yang harmonis dan kondusif. Hal ini berarti bahwa seluruh komponen pendidikan di sekolah harus dikembangkan secara terpadu dalam rangka meningkatkan relevansi atau kesesuaian dengan kualitas pendidikan (Mulyasa, 2007: 25).

Dari pendapat sejumlah ahli di atas dapat dipahami bahwa, Kepala Sekolah adalah guru yang mendapat tugas tambahan sebagai Kepala Sekolah atau pimpinan dari sebuah lembaga pendidikan. Meskipun guru yang mendapat tugas tambahan Kepala Sekolah merupakan orang yang paling betanggung jawab terhadap prinsip-prinsip administrasi pendidikan yang inovatif di sekolah. Sebagai orang yang mendapatkan tugas tambahan berarti tugas pokok Kepala Sekolah tersebut adalah guru yaitu sebagai tenaga pengajar dan pendidik, maksudnya dalam suatu sekolah seorang Kepala Sekolah harus mempunyai tugas sebagai seorang guru yang melaksanakan atau memberikan pelajaran atau mengajar bidang studi tertentu atau memberikan 
bimbingan. Berarti dalam hal ini, Kepala Sekolah memiliki dua fungsi yaitu sebagai tenaga kependidikan dan tenaga pendidik.

Keberhasilan Kepala Sekolah dalam mengelola sekolahnya tidak terlepas dari kemampuan Kepala Sekolah sebagai pemimpin dalam melaksanakan peran serta fungsi manajerial di lembaga yang dipimpinnya. Maka dari itu seorang Kepala Sekolah dituntut memiliki kecakapan serta kesiapan dalam mengelola sekolah. Kecakapan dan kesiapan yang dimaksud adalah kemampuan manajerial sebagaimana diatur dalam Permendiknas No 13 Tahun 2007 Tentang Standar Kepala Sekolah/Madrasah, yang meliputi: perencanaan, pengorganisasian, pengarahan dan pengawasan. Dengan kemampuan manajerial yang baik diharapkan setiap Kepala Sekolah mampu meningkatkan kualitas serta menjadi pendorong dan penegak disiplin bagi para guru agar mereka mampu menunjukkan profesionalisme dan produktivitas kinerja secara maksimal. Dengan perkataan lain, keberhasilan sekolah memerlukan adanya kepemimpinan Kepala Sekolah yang berkualitas. Hal itu diharapkan akan terwujud manakala Kepala Sekolah menguasai 3 (tiga) kemampuan dasar yaitu 1) kemampuan konseptual (conceptual skills), 2) kemampuan kemanusiaan (human skills) dan 3) kemampuan teknis (technical skills) (Wahjosumidjo, 2013: 349).

Jadi, Kepala Sekolah mempunyai peranan sangat penting dalam peningkatan mutu pendidikan di lembaga yang dipimpinnya. Mutu pendidikan akan dapat ditingkatkan apabila Kepala Sekolah memiliki kompetensi yang memadai baik dibidang manajerial, kewirausahaan, kepribadian maupun supervisi. Dapat dikatakan bahwa kualitas pendidikan di sekolah merupakan hasil dari keefektifan manajerial Kepala Sekolah yang juga didukung oleh guru dan semua warga sekolah. Hal ini sejalan dengan penelitian terdahulu yang dilakukan oleh Darmada (2013: 1) yang menyatakan bahwa Kepala Sekolah selaku manajer di sekolah memberikan kontribusi terhadap kemajuan pendidikan di sekolah, selain itu juga pendidik dan tenaga kependidikan juga mempunyai peranan yang tidak kalah penting dalam keberhasilan didunia pendidikan. Di lain pihak Hermawan (2010: 1) menemukan bahwa faktor penghambat suatu program yang dijalankan di sekolah lebih banyak disebabkan oleh peserta didik, pendidik dan tenaga kependidikan, dana, sarana prasarana, serta patisipasi masyarakat.

Masalah kinerja mengajar guru juga merupakan hal penting yang seharusnya diperhatikan oleh Kepala Sekolah selaku pimpinan lembaga pendidikan. Isjoni (2009) menjelaskan bahwa bila diamati di lapangan guru sudah berusaha menunjukkan kinerja maksimal di dalam menjalankan tugas dan fungsinya sebagai pendidik, pengajar, dan pelatih. Pada umumnya guru telah berusaha untuk melakukan yang terbaik, tetapi tidak semua guru bisa melaksanakan pembelajaran dengan baik, hal inilah yang akan menjadikan kinerja guru masih tampak kurang maksimal. Padahal kinerja mengajar guru dalam meningkatkan prestasi belajar siswa yang optimal, merupakan salah satu kekuatan yang penting dalam proses pendidikan. Oleh karena itu Sagala (2010: 88) menegaskan bahwa prestasi kerja guru dan karyawan bahkan menjadi tolok ukur dari berhasil atau tidaknya kinerja seorang Kepala Sekolah.

Program Manajerial Kepala Sekolah pada dasarnya merupakan kemampuan kognitif, kemampuan afektif dan kemampuan psikomotorik. Melalui program manajerial Kepala Sekolah mengelola pendidikan di sekolah dengan memanfaatkan semua sumber daya yang ada termasuk manusia dan juga sumber daya lainnya untuk mencapai tujuan pendidikan yang bermutu. Berdasarkan pendapat diatas dapat diketahui bahwa program manajerial Kepala Sekolah adalah kemampuan Kepala Sekolah sebagai manajer yang 
Kelola: Jurnal Manajemen Pendidikan, Vol. 5, No. 2, Juli-Desember 2018

menjalankan fungsi fungsi manajemen yaitu: (a) kemampuan merencanakan dengan indikator yaitu mampu menyusun dan menerapkan strategi, dan mampu mengefektifkan perencanaan, (b) kemampuan mengorganisasikan dengan indikator mampu melakukan departementalisasi, membagi tanggung jawab dan mampu mengelola personil, (c) kemampuan dalam pelaksanaan dengan indikator yaitu mampu mengambil keputusan, dan mampu menjalin komunikasi,

(d) kemampuan mengadakan pengawasan dengan indikator mampu mengelola, dan mampu mengendalikan operasional serta mampu menjalankan peranannya sebagai manajer agar tercapai tujuan organisasi yang telah ditetapkan (Lazarus, $1986: 43$ ).

Kepala Sekolah sebagai seorang pemimpin diharapkan mempunyai peranan sebagai manajer dalam menjalankan kewajibannya. Mintzberg (2006: 12), mengemukakan ada tiga peranan utama yang harus dimainkan oleh seorang manajer yaitu: Pertama, peranan hubungan antar pribadi (Interpersonal Role). Peranan ini bertalian dengan status dan otoritas manjer dan hal-hal yang berhubungan dengan pengembangan hubungan antar pribadi dengan perincian sebagai berikut: (1) Peranan sebagai Figurehead, peranan yang sangat dasar dan sederhana dilakukan untuk mewakili organisasi yang dipimpinnya dalam setiap kesempatan dan persoalan yang timbul secara formal, (2) Peranan sebagai pimpinan (leader), yaitu melakukan hubungan interpersonal dengan yang dipimpin dan melakukan fungsi-fungsi pokoknya, dan (3) Peranan sebagai pejabat perantara (liaison manager), yaitu melakukan interaksi dengan teman sejawat, staf, orangorang diluar organisasinya untuk mendapatkan informasi.

Kedua, peranan yang berhubungan dengan informasi (Informasional Role). Manajer sebagai pusat informasi bagi organisasinya, yaitu (1) sebagai monitor, yaitu seorang manajer sebagai penerima dan pengumpul informasi guna mengembangkan pengertian yang baik dari organisasi yang dipimpinnyadan pemahaman yang komprehensif tentang lingkungan, (2) sebagai dessiminator, yaitu menangani proses transmisi dari informasi informasi ke dalam organisasi yang dipimpinnya, yaitu penyampaian informasi dari luar ke dalam organisasinya, dan juga dari bawahan atau staf ke bawahan atau staf yang lainnya, dan (3) sebagai jurubicara (spokerman), yaitu manajer mewakili dan bertindak atas nama organisasi menyampaikan informasi keluar lingkungan organisasinya.

Ketiga, peranan pembuat keputusan (Decissional Role). Merupakan peranan yang tidak boleh tidak dijalankan karena seorang manajer harus terlibat langsung dalam proses pembuatan strategi organisasi. Peranan ini dikelompokkan sebagai berikut: (1) Sebagai entrepreneur, yaitu manajer bertindak sebagai pemprakarsa dan perancang dalam organisasi dengan memfokuskan pada pekerjaan manajerial dengan mulai aktivitas melihat atau memahami masalah- masalah dalam organisasi yang mungkin dapat diselesaikan, (2) Sebagai penghalau gangguan (disturbance handler), yaitu manajer bertanggung jawab mengatasi ancaman bahaya atau perbuatan yang tidak diketahui sebelumnya yang menganggu atau memungkinkan timbulnya krisis di dalam organisasi, (3) Sebagai suatu pembagi sumber (resource allocator), yaitu memutuskan pendistribusian sumber dana ke bagian-bagian organisasi guna mempermudah pelaksanaan kerja, dan (4) Sebagai negosiator, yaitu aktif berpartisipasi atau terlibat dalam negosiasi dengan pihak-pihak lain baik diluar maupun didalam organisasi.

Kepala Sekolah merupakan kunci bagi terselenggaranya iklim organisasi sekolah yang kondusif dengan dinamika perubahan yang selalu dilakukan secara terus menerus. Manajemen merupakan suatu komponen yang tidak bisa dipisahkan dari dunia pendidikan. 
Disamping itu sebagai agen perubahan, maka Kepala Sekolah tentu saja harus memahami dan mengembangkan keterampilannya dalam melaksanakan perubahan itu, apabila Kepala Sekolah ingin sekolah yang dipimpinnya menjadi lebih efektif Wahjosumidjo (2001:170-171). Sesuai dengan penilaian kinerja, Kepala Sekolah harus memiliki kemampuan dalam melaksanakan semua tugas-tugas kepemimpinannya yang diwujudkan dalam kemampuannya menyusun program sekolah, organisasi personalia, memberdayakan tenaga kependidikan, dan mendayagunakan sumber daya sekolah secara optimal.

Menuurut Mulyasa (2003: 106) kemampuan menyusun program sekolah diwujudkan dalam : (1) pengembangan program jangka panjang, baik program akademis maupun nonakademis, yang dituangkan dalam kurun waktu lebih dari lima tahun, (2) pengembangan program jangka menengah baik program akademis maupun nonakademis, yang dituangkan dalam kurun waktu tiga sampai lima tahun, dan (3) pengembangan program jangka pendek baik program akademis maupun nonakademis, yang dituangkan dalam kurun waktu satu tahun (program tahunan), termasuk pengembangan rencana anggaran pendapatan belanja sekolah.

Kemampuan memberdayakan tenaga kependidikan di sekolah diwujudkan dalam pemberian arahan secara dinamis, pengkoordinasian tenaga kependidikan dalam pelaksanaan tugas, pemberian hadiah bagi mereka yang berprestasi, dan pemberian hukuman bagi mereka yang kurang disiplin dalam melaksanakan tugas dan tanggung jawabnya dalam sebuah institusi atau lembaga pendidikan tersebut

Sejauh ini telah terdapat sejumlah penelitian di bidang program manajerial Kepala Sekolah dengan hasil yang bervariasi. Penelitian yang dilakukan oleh Ekosiswoyo (2007) dengan judul Kepemimpinan Kepala
Sekolah yang Efektif Kunci Pencapaian Kualitas Pendidikan menunjukan bahwa Kepala Sekolah merupakan salah satu faktor kunci dalam menentukan terciptanya pendidikan yang berkualitas. Mengacu pada fungsi dan perannya, Kepala Sekolah berperan sebagai manajer dan pemimpin institusi pendidikan sekolah. Manajemen dan kepemimpinan yang efektif memerlukan Kepala Sekolah yang mewujudkan pemodelan dan kepemimpinan yang transformasional, ditunjukkan oleh karakteristik seperti pengaruh ideal, motivasi inspirasi, stimulasi intelektual dan pertimbangan individual. Mereka harus memberdayakan staf pengajar, bekerja berdasarkan kerangka waktu yang jelas, membangun hubungan interpersonal, mengembangkan prinsip-prinsip yang adil dan dapat dipertanggung jawabkan dan dapat bekerja dalam tim.

Penelitian Suratman (2010) dengan judul Kompetensi Manajerial Kepala Sekolah, Ketersediaan Sarana Prasarana, Kapabilitas Mengajar Guru, dan Dukungan Orang Tua, Kaitannya dengan Prestasi Belajar Siswa SMP Negeri Kota Surabaya menunjukkan bahwa prestasi siswa dipengaruhi oleh banyak faktor, seperti kompetensi manajerial Kepala Sekolah, kompetensi mengajar guru, dukungan orang tua, dan juga fasilitas sekolah. Ditemukan pula bahwa ada hubungan langsung yang signifikan antara kelima variabel penelitian tersebut. Untuk memperbaiki prestasi siswa, peneliti menyarankan agar: (1) Kepala Sekolah mengoptimalkan perannya sebagai manajer (2) guru meningkatkan kompetensinya (3) orang tua meningkatkan partisipasi suportif mereka, baik untuk kegiatan belajar mengajar anak-anak mereka maupun ke sekolah sebagai administrator proses belajar mengajar.

Sementara itu penelitian Taswir (2014) dengan judul Manajerial Kepala Sekolah Dalam Meningkatkan Kinerja Guru pada Sekolah Menengah Kejuruan (SMK) Negeri 2 Sinabung Kabupaten Simeulue Banda Aceh, 
Kelola: Jurnal Manajemen Pendidikan, Vol. 5, No. 2, Juli-Desember 2018

menunjukkan bahwa: (1) kemampuan manajerial Kepala Sekolah dalam menyusun program perencanaan dirumuskan oleh Kepala Sekolah dimulai pada tahun ajaran baru dengan kegiatan antara lain: melaksanakan supervisi, penilaian kinerja guru, mengikutsertakan guru untuk mengikuti pelatihan, pembagian tugas tambahan bagi guru misalnya sebagai wakil Kepala Sekolah, ketua jurusan, kepala laboratorium, pembimbing, dan pengelola perpustakaan; (2) strategi yang dilakukan Kepala Sekolah dalam pelaksanaan kinerja guru kemampuan profesional guru telah dilakukan antara lain, membimbing guru dalam menyusun perangkat pembelajaran, menerapkan berbagai model terkait dengan pembelajaran, memberikan motivasi, mengikutsertakan guru-guru dalam berbagai kegiatan pelatihan atau penataran, dan memberikan kesempatan bagi guru untuk melanjutkan studi, serta mengaktifkan kegiatan forum MGMP dan KKG di sekolah; (3) dampak yang ditimbulkan dari proses pembinaan yang dilakukan Kepala Sekolah untuk meningkatkan kinerja guru, akan tampak dari adanya perubahan sikap guru-guru yang mengarah kepada perubahan yang lebih baik, yaitu kemampuan guru dalam merencanakan, melaksanakan dan menilai proses pembelajaran; (4) kendala yang dihadapi dalam upaya peningkatan kemampuan profesional guru antara lain, menyangkut masalah keterbatasan biaya, keterbatasan waktu, dan terbatasnya sumber daya manusia, serta terbatasnya pelatihan atau penataran yang diadakan sehubungan dengan peningkatan kemampuan profesional guru.

Penelitian Jay (2014) dengan judul "The Principals Leadership Style and Teachers Performance in Secondary Schools of Gambella Regional State, Ethiopia" menunjukkan bahwa Kepala Sekolah memiliki pengaruh yang signifikan terhadap pengambilan keputusan, termasuk komunikasi dan pendelegasian untuk meningkatkan kinerja guru. Kepemimpinan Kepala Sekolah yang bermutu tentu saja akan menghasilkan kinerja yang baik bagi guru-guru dan akan sangat berdampak pada prestasi peserta didik.

Penelitian juga dilakukan oleh Zulkarnaen (2016) dengan judul "Kompetensi Manajerial Kepala Sekolah Dalam Meningkatkan Kinerja Guru Pada SMP Islam Terpadu Kabupaten Aceh" dengan hasil bahwa program Kepala Sekolah dalam meningkatkan kinerja guru adalah dengan program pelatihan guru, seminar pendidikan, workshop guru, MGMP,KKG, memberi penghargaan guru yang berprestasi dan juga menambah intensif guru serta memberi kesempatan kepada guru untuk menggunakan perangkat IT dalam pembelajaran.

Dari beberapa penelitian terdahulu terkait evaluasi program, terutama program manajerial Kepala Sekolah, dimana hampir semua penelitian terdahulu membahas mengenai keberhasilan seorang Kepala Sekolah dalam memimpin dan mengelola suatu program di sekolah tersebut, hal ini menandakan bahwa program manajerial Kepala Sekolah mempunyai pengaruh positif terhadap kinerja baik Kepala Sekolah itu sendiri dan juga guru dalam pelaksanaan pengelolaan programprogram yang ada di sekolah, pembelajaran yang berkitan dengan kemampuan guru dalam merencanakan, melaksanakan dan menilai pembelajaran, baik yang berkaitan dengan proses pembelajaran maupun hasil kerjanya. Dalam hal ini peneliti tertarik ingin meneliti mengenai program manajerial Kepala Sekolah dalam meningkatkan kinerja mengajar guru di SD Swasta di Kota Salatiga.

Persoalan mendasar terkait dengan kompetensi manajerial Kepala Sekolah di SD swasta yang hendak diteliti ini adalah: (1) Kepala Sekolah masih belum terlalu memahami Permendiknas Nomor 13 Tahun 2007 sehingga belum mampu menjalankan tugas dan tanggung jawabnya secara optimal, (2) keterlibatan guru dalam penyusunan perencanaan program- 
program sekolah yang merupakan refleksi dari kompetensi manajerial masih belum maksimal, dan (3) Kepala Sekolah masih belum bisa menggerakkan iklim organisasi secara sehat, misalnya dalam mengoptimalkan sumber daya yang ada di sekolah. Dari hasil wawancara dengan Kepala Sekolah, diketahui bahwa sejak awal dijalankannnya program-program sekolah mulai tahun 2005 sampai tahun 2018, sudah 13 tahun semenjak yang bersangkutan menjabat sebagai Kepala Sekolah, belum pernah dilakukan evaluasi program manajerial Kepala Sekolah. Maka dari itu, peneliti tertarik untuk melakukan evaluasi terhadap program manajerial Kepala Sekolah.

Arikunto dan Jabar (2014: 17) menyatakan bahwa evaluasi program adalah upaya untuk mengetahui efektivitas komponen program dalam mendukung pencapaian tujuan program. Sedang tujuan evaluasi program menurut Wirawan (2011: 54) adalah untuk menentukan apakah layanan atau intervensinya telah mencapai tujuan yang ditetapkan dan supaya dapat diketahui dengan pasti apakah pencapaian hasil, kemajuan dan hambatan yang dijumpai dalam pelaksanaan program dapat dinilai dan dipelajari untuk perbaikan pelaksanaan program dimasa yang akan mendatang.

Penelitian ini menggunakan model evaluasi CIPP yang dikembangkan oleh Stufflebeam tahun 1966 (Wirawan, 2011: 92). Komponen dalam model evaluasi CIPP dapat dijelaskan sebagai berikut: (1) Evaluasi context berupaya mengidentifikasi mengenai kebutuhan lingkungan yang belum terpenuhi, populasi sampel yang dilayani dan tujuan program. (2) Evaluasi input berupaya mengidentifikasi tentang kemampuan awal dari komponen yang ada dalam menunjang pelaksanaan program tersebut. (3) Evaluasi process mengidentifikasi mengenai pelaksanaan program yang meliputi program apa yang akan dilaksanakan, dan siapa penyelenggara program, dan waktu pelaksanaan program. (4) Evaluasi product berupaya untuk mengidentifikasi perubahan yang terjadi akibat pelaksanaan program, serta ketercapaian tujuan program.

Berdasarkan masalah diatas, tujuan penelitian ini adalah untuk mengevaluasi context, input, process, dan product program manajerial Kepala Sekolah dalam meningkatkan kinerja mengajar guru di SD Swasta Salatiga.

\section{METODE PENELITIAN}

Penelitian ini termasuk penelitian kualitatif yang bersifat evaluatif dengan model CIPP. Penelitian dilaksanakan di salah satu SD Swasta di Kota Salatiga. Sumber informasi meliputi Kepala Sekolah dan Guru. Sumber data mengenai program manajerial Kepala Sekolah juga berupa dokumen-dokumen, Juknis, Surat Keputusan penyelenggaraan kegiatan, jadwal penyelenggaraan kegiatan, rencana program dan laporan penyelenggaraan program. Teknik pengumpulan data yang digunakan dalam penelitian ini adalah wawancara, observasi, dan studi dokumen. Tahapan yang dilakukan dalam analisis data penelitian meliputi: (1) pengumpulan data, (2) reduksi data, (3) display data, (4) verifikasi data. Uji validitas data yang digunakan dalam penelitian ini adalah teknik triangulasi sumber dan triangulasi teknik.

\section{HASIL PENELITIAN DAN PEMBAHASAN}

\section{Hasil Penelitian}

Evaluasi Context Program Manajerial Kepala Sekolah

Pada tahap context, peneliti menganalisis kebutuhan program, tujuan, manfaat, serta sasaran program manajerial Kepala Sekolah di SD Swasta ini Berdasarkan hasil wawancara dan telaah dokumen, latar belakang dilaksanakannya program manajerial Kepala Sekolah adalah sebagai bentuk dari kerjasama antara Kepala Sekolah dan guru 
dalam menciptakan suasana yang aman dan kondusif sehingga memungkinkan terciptanya iklim belajar yang baik bagi siswa dan juga guru. Program manajerial Kepala Sekolah di SD Swasta ini belum pernah dilakukan penelitian dan kinerja guru di sekolah tersebut juga masih rendah. Tujuan program manajerial Kepala Sekolah di SD Swasta ini adalah untuk mengetahui secara rinci tindakan yang seharusnya dilakukan terkait program-program sekolah, memberikan arahan kepada Kepala Sekolah untuk mewujudkan visi dan misi sekolah, memberikan arahan dan target mengenai apa saja yang perlu dikembangkan dalam proses pembelajaran yang efektif, meningkatkan dan melatih kemampuan seorang Kepala Sekolah dalam menyusun programprogram sekolah serta memberikan arahan terhadap warga sekolah untuk menyusun perencanaan program sekolah. Manfaat yang diharapkan dari program Manajerial Kepala Sekolah adalah untuk memperluas pengetahuan, memperdalam, memperkaya konsep mengenai program manajerial Kepala Sekolah, mengetahui apakah Kepala Sekolah sudah berhasil dalam melaksanakan program, dan mengelola guru-guru. Sasaran dari program manajerial Kepala Sekolah yaitu: Kepala Sekolah, tenaga pendidik dan kependidikan, dan juga peserta didik.

\section{Evaluasi Input Program Manajerial Kepala Sekolah}

Pada tahap input, peneliti mengevaluasi mengenai rencana pelaksanaan program, mekanisme pelaksanaan, Sumber Daya Manusia (SDM), pembiayaan, dan sarana prasarana terkait program manajerial Kepala Sekolah di SD Swasta ini. Berdasarkan hasil wawancara, observasi dan studi dokumen didapati bahwa rencana program manajerial tentang program pembelajaran dan kurikulum, kepegawaian, kesiswaan, keuangan, dan juga sarpras pendukung sudah didesain sedemikian rupa dengan mempertimbangkan berbagai aspek oleh Kepala Sekolah. Dalam dokumen perencanaan program terdapat beberapa point, yaitu: program kerja Kepala Sekolah, program kerja tahunan Kepala Sekolah, program kerja Kepala Sekolah (pengajaran), agenda harian Kepala Sekolah, jadwal kegiatan sekolah, jadwal mata pelajaran, KKM dan SKL, struktur kurikulum, rekapitulasi keadaan pegawai, administrasi sekolah dasar, dan lain-lain. Di dalam rencana itu juga dirinci beberapa macam kegiatan yang akan dilaksanakan, jadwal pelaksanaan kegiatan, siapa saja yang bertanggung jawab, sarpras yang dibutuhkan, serta anggaran pembiayaan yang digunakan.

Mekanisme pelaksanaan program manajerial Kepala Sekolah yang dilaksanakan di SD Swasta ini berpedoman pada juknis yang ada dan disesuaikan dengan kebutuhan sekolah.

Selanjutnya terkait dengan SDM yang ada, dari segi kuantitas masih belum memenuhi standar karena sekolah ini kekurangan tenaga pendidik, jumlah peserta didik juga sangat fluktuatif, sedang fasilitas pendukung proses belajar mengajar juga masih kurang. Dana bersumber dari yayasan, BOS dan bantuan pihak ketiga yang dirasa belum mencukupi kebutuhan sekolah.

\section{Evaluasi Process Program Manajerial Kepala Sekolah}

Dari segi process program manajerial Kepala Sekolah dilaksanakan berdasarkan fungsi-fungsi manajemen yakni: perencanaan, pengorganisasian, pengawasan, dan penilaian. Hal ini dilakukan guna mengatur sumber daya yang ada secara efektif dan efisien dalam mencapai tujuan sekolah yang telah ditetapkan. Program-program yang dilaksanakan dalam bentuk pembinaan pemanfaatan KKG, MGMP, supervisi secara rutin, hal ini diharapkan untuk mengetahui secara detail dari proses kegiatan belajar mengajar oleh guru-guru dan juga memberikan dukungan kepada guru-guru untuk berkreasi sesuai dengan kompetensinya. Sekolah juga memberi kesempatan kepada guru untuk mengikuti seminar ataupun workshop 
yang diharapkan bisa menambah wawasan mereka.

Meskipun secara umum proses manajerial Kepala Sekolah sudah berjalan dengan baik, namun masih terdapat juga beberapa permasalahan yang ada terutama pada guru-guru, dimana didapatkan bahwa kinerja guru masih kurang dan motivasi guru juga masih kurang. Dalam implementasi kurikulum (kurikulum yang digunakan adalah KTSP) hasil penelitian menunjukkan bahwa (1) pada sisi perencanaan guru yang idealnya memiliki kompetensi untuk membuat desain instruksional sesuai dengan faedah-faedah pedagogik yang dituangkan dalam rencana pelaksanaan pembelajaran (RPP), dalam kenyataan terwujud sesuai dengan ketentuan yang ada. dan (2) pada pelaksanaannya terkait dengan manajemen kurikulum, dimana guru yang seharusnya memiliki kompetensi penguasaan materi pembelajaran sesuai dengan bidang keahlian yang dimilikinya masingmasing, namun pada kenyataannya pada saat melakukan PBM masih ada guru yang mengajar belum sesuai dengan materi atau tema yang ada, hal ini dibuktikan dengan terbatasnya alat peraga atau media pembelajaran sehingga guru menjelaskan terkadang masih belum sesuai dengan tema atau topik yang diajarkan sehingga siswa terlihat masih belum memahami materi. Guru sudah membuat RPP sesuai dengan tema pembelajaran, namun pada saat mengajar materi yang diajarkan masih belum sesuai dengan RPP yang ada dan lebih banyak mengambil bahan ajar di Lembar Kerja Siswa (LKS).

Dari segi pendanaan sekolah ini juga menerima dana Bantuan Operasional Sekolah (BOS) dari pemerintah. Mekanisme penyaluran dana dari pusat ke sekolah sudah jelas mulai dari prosesnya sampai ke jumlahnya. Penggunaan dana BOS juga sudah dilakukan sesuai dengan prosedur dari pemerintah. Namun dengan dana yang terbatas itu membuat sekolah harus bijak dalam menyelenggrakan berbagai program, dengan cara membuat skala prioritas. Di samping itu penyelenggaraan program-program sekolah juga didanai melalui bantuan para donatur, alumni, orang tua siswa, dan juga pihak yayasan. Tampak bahwa pemerintah tidak sepenuhnya membiayai program-program sekolah, karena memang dana yang didapatkan dari pemerintah lebih banyak dialokasikan pada pembangunan fisik sesuai dengan kebutuhan sekolah tersebut serta untuk peserta didik yang kurang mampu, di mana beberapa anak dari keluarga yang kurang mampu tidak dipungut biaya sama sekali oleh pihak sekolah. Sementara itu dukungan dana dari pemerintah daerah melalui alokasi pendanaan dalam APBD masih belum ada.

\section{Evaluasi Product Program Manajerial Kepala Sekolah}

Dari segi product program manjerial Kepala Sekolah hasil evaluasi menunjukkan bahwa semua program manajerial Kepala Sekolah sudah dilaksanakan dengan baik, walaupun terdapat juga faktor pendukung dan penghambat, karena hasil akhir dari pekerjaan tentu saja dipengaruhi oleh sumber daya dan lingkungan yang berinteraksi secara bersama untuk mencapai tujuan sekolah dalam mencapai visi dan misinya. Jika hasil dari suatu kinerja dapat tercapai atau melebihi dengan apa yang diharapkan, baik secara kualitas maupun kuantitas, maka hasil tersebut dapat dikatakan memuaskan. Secara umum program-program di sekolah SD Swasta ini sudah bisa dikatakan sudah tercapai meskipun belum maksimal, sehingga perlu adanya perbaikan dalam pelaksanaannya.

\section{Pembahasan}

Dari segi context keberadaan program manajerial Kepala Sekolah SD Swasta ini selain merupakan pelaksanaan kebijakan dari Pemerintah, juga memang dibutuhkan oleh sekolah mengingat kinerja mengajar guru di sekolah tersebut masih rendah. Tujuan program manajerial Kepala Sekolah di SD Swasta ini adalah untuk mengetahui secara rinci tindakan 
yang seharusnya dilakukan terkait programprogram sekolah, memberikan arahan kepada Kepala Sekolah untuk mewujudkan visi dan misi sekolah, memberikan arahan dan target mengenai apa saja yang perlu dikembangkan dalam proses pembelajaran yang efektif, meningkatkan kemampuan Kepala Sekolah dalam menyusun program-program sekolah, serta memberikan arahan terhadap warga sekolah untuk menyusun perencanaan program program sekolah. Kesemua hal di atas diharapkan akan berpengaruh terhadap kinerja guru dalam mengelola proses belajar mengajar di sekolah sehingga terjadi peningkatan mutu pendidikan di sekolahyang bersangkutan.

Hasil penelitian tersebut sejalan dengan temuan Safitri (2015) yang mengatakan bahwa peranan Kepala Sekolah sebagai manajer dalam mengelola sekolah merupakan faktor kunci keberhasilan sekolah termasuk meningkatkan kinerja guru. Temuan di atas juga sejalan dengan hasil penelitian Ekosiswoyo (2007) yang menunjukan bahwa Kepala Sekolah merupakan salah satu faktor kunci dalam menentukan terciptanya pendidikan yang berkualitas.

Dari segi input program manajerial Kepala Sekolah sudah terencana dan terkonsep dengan baik, mekanisme pelaksanaan program manajerial Kepala Sekolah juga sudah cukup jelas sesuai dengan prosedur yang sudah ditetapkan dalam juknis dan tentu saja disesuaikan dengan kebutuhan sekolah. Namun program itu sendiri masih belum memenuhi standar pendidikan dan masih belum cukup mendapat topangan yang memadai. Dari segi sarpras apa yang tersedia di SD Swasta ini masih belum memenuhi kriteria yang ditentukan. Dari segi SDM juga masih belum memenuhi standar, sementara kurikulum juga masih perlu evaluasi lebih lanjut. Dari segi anggaran juga masih belum mencukupi. Hasil penelitian ini perlu dikonfirmasi dengan temuan Ahmad \& Ahmad (2013) yang menyatakan bahwa keberhasilan pencapaian suatu program dipengaruhi oleh ketersediaan dana. Akan kita lihat dalan evaluasi produk di bawah nanti apakah produk sekolah ini terkendala oleh kurangnya dana, SDM dan sarana prasaran sekolah.

Dari segi process bahwa program manajerial Kepala Sekolah dilaksanakan berdasarkan fungsi-fungsi manajemen yakni: perencanaan, pengorganisasian, pengawasan, dan penilaian. Program-program yang dilaksanakan dalam bentuk pembinaan guru melalui pemanfaatan KKG, MGMP, mengikutsertakan guru dalam seminar-seminar ataupun workshop yang diharapkan bisa menambah wawasan para guru. Supervisi akademik juga dilaksanakan secara rutin guna mengetahui secara detail dari proses KBM yang dilaksanakan oleh guru-guru dan juga memberikan dukungan kepada guru-guru untuk berkreasi sesuai dengan kompetensinya. Temuan di atas sejalan dengan hasil penelitian Taswir (2014) yang menunjukkan bahwa Kepala Sekolah juga mengikutsertakan guruguru dalam berbagai kegiatan pelatihan atau penataran, dan memberikan kesempatan bagi guru untuk melanjutkan studi, serta mengaktifkan kegiatan forum MGMP dan KKG di sekolah. Temuan diatas juga sejalan dengan temuan Zulkarnaen (2016) bahwa program Kepala Sekolah dalam meningkatkan kinerja guru adalah dengan program pelatihan guru, seminar pendidikan, workshop guru, MGMP, KKG, memberi penghargaan guru yang berprestasi dan juga menambah insentif guru serta memberi kesempatan kepada guru untuk menggunakan perangkat IT dalam pembelajaran. Perlu dicatat bahwa di SD Swasta ini belum ada pemberian penghargaan guru yang berprestasi dan juga menambah insentif guru serta memberi kesempatan kepada guru untuk menggunakan perangkat IT dalam pembelajaran.

Meskipun prosesnya sudah berjalan dengan baik, namun masih terdapat juga beberapa permasalahan terutama pada guru- 
guru, dimana didapatkan bahwa kinerja guru masih kurang dan selanjutnya ditemukan juga kendala yaitu peran aktif pendidik memang belum bisa berjalan dengan baik, dan motivasi guru juga masih kurang. Temuan di atas menggarisbawahi pandangan Majid (2006) yang menyatakan bahwa pengembangan pembelajaran perlu dikelola dengan baik agar dapat mencapai hasil yang optimal. Hasil penelitian di atas juga membuktikan pentingnya peranan Kepala Sekolah dalam penyelenggaraan pendidikan di sekolah sebagaimana ditemukan dalam penelitian Jay (2014) yang menunjukkan bahwa Kepala Sekolah memiliki pengaruh yang signifikan terhadap pengambilan keputusan, termasuk komunikasi dan pendelegasian untuk meningkatkan kinerja guru. Kepemimpinan Kepala Sekolah yang bermutu tentu saja akan menghasilkan kinerja yang baik bagi guru-guru dan akan sangat berdampak pada prestasi peserta didik.

Dari sisi product program manajerial Kepala Sekolah prestasi yang diraih oleh siswa/i SD Swasta ini memang relatif cukup banyak namun hampir semuanya di bidang non akademik. Sedang di bidang non akademik capaian sekolah ini belum optimal walau memang terjadi perbaikan. Hasil rata-rata nilai Ujian Nasional mulai dari tahun ajaran 2014/2015 sampai 2016/2017 semakin naik walaupun tidak drastis, Kriteria Ketuntasan Minimal (KKM) dan SKL juga sudah sesuai dengan standar yang ditentukan, angka mengulang kelas pada 2015/2016 hanya satu orang dan mulai 2016/2017 sudah tidak ada angka mengulang kelas, angka kelulusan 100\% setiap tahunnya, dan angka yang melanjutkan ke SLTP mencapai 95\% setiap tahunnya.

Meskipun terkendala dari sisi pendanaan, SDM dan juga sarpras yang kurang memadai, namun sekolah tetap masih bisa melaksanakan program dengan dana serta sarpras seadanya. Oleh karena itu dapat dipahami jika pada akhir prestasi sekolah ini belum cukup memadai.

Hasil penelitian ini menggaris bawahi temuan penelitian terdahulu yang dilakukan oleh Ahmad \& Ahmad (2013) yang menyatakan bahwa keberhasilan pencapaian suatu program dipengaruhi oleh ketersediaan dana. Hasil di atas juga membuktikan temuan Suratman (2010) bahwa prestasi siswa dipengaruhi oleh banyak faktor, seperti kompetensi manajerial Kepala Sekolah, kompetensi mengajar guru, dukungan orang tua, dan juga fasilitas sekolah. Hasil penelitian di atas juga membenarkan temuan Hermawan (2010: 1) bahwa faktor penghambat suatu program yang dijalankan di sekolah lebih banyak disebabkan oleh peserta didik, pendidik dan tenaga kependidikan, dana, sarana prasarana, serta patisipasi masyarakat.

\section{SIMPULAN DAN SARAN Simpulan}

Hasil evaluasi diatas menunjukkan bahwa, dari segi context, program manajerial Kepala Sekolah di SD Swasta ini memang sangat dibutuhkan oleh sekolah terutama Kepala Sekolah dalam mengelola dirinya sendiri, guru dan semua warga sekolah. Dari segi input, sudah disusun program manajerial Kepala Sekolah untuk memenuhi kebutuhan stakeholder di SD Swasta ini namun belum ditopang dengan sumber daya manusia (SDM), pendanaan, dan sarana prasarana yang memadai. Dari segi process program manajerial Kepala Sekolah dilaksanakan berdasarkan fungsi-fungsi manajemen yakni: perencanaan, pengorganisasian, pengawasan, dan penilaian. Meskipun terkendala dari sisi pendanaan, SDM dan juga sarpras yang kurang memadai, namun Kepala Sekolah tetap masih bisa melaksanakan program manajerial dengan dana serta sarpras seadanya. Dari segi product SD Swasta ini lebih berprestasi dalam bidang non akademik katimbang di bidang akademik 
Kelola: Jurnal Manajemen Pendidikan, Vol. 5, No. 2, Juli-Desember 2018

walaupun dari tahun ketahun terjadi sedikit peningkatan kualitas hasil belajar siswa.

\section{Saran}

Terdapat beberapa saran yang peneliti sampaikan guna perbaikan penyelenggaraan pendidikan di sekolah pada periode berikutnya, sebagai berikut,

(1) Bagi guru, diharapkan agar meningkatkan kinerja mengajarnya terutama dengan mengikuti program seperti KKG dan MGMP, serta memanfaatkan IT sebagai media pembelajaran.

(2) Bagi Kepala Sekolah, hendaknya lebih optimal dalam menjalin kerjasama yang baik dengan pihak luar untuk mendapatkan bantuan dana dalam mendukung pelaksanaan program. SDM yang ada perlu ditingkatkan, sarana dan prasarana perlu ditinjau kembali agar bisa menunjang kebutuhan sekolah, dan Kepala Sekolah harus mengoptimalkan peranannya sebagai manajer dalam melaksanakan program manajerial Kepala Sekolah sehingga dapat meningkatkan kompetensi dan kinerja guru.

(3) Bagi Yayasan, diharapkan agar lebih memberikan bantuan baik berupa materi, dorongan, motivasi, dan juga evaluasi kepada Kepala Sekolah dan guru serta semua warga sekolah, agar dalam proses pembelajaran semakin baik dan kinerja guru pun meningkat.

\section{UCAPAN TERIMAKASIH}

Terimakasih yang tulus diberikan kepada Dr. Ade Iriani, MM yang menjadi Pembimbing II dalam penulisan Tesis yang substansinya kemudian tersaji dalam bentuk artikel ini.

\section{DAFTAR PUSTAKA}

Ahmad, A., \& Ahmad, N. 2013. Role of packaging in consumer buying behavior. International Review of Basic and Applied Sciences, 1(2), 35-41.
Arikunto, Suharsimi.dan Safruddin Abdul Jabar, Cepi. 2014. Evaluasi Program Pendidikan.Jakarta: PT Bumi Aksara.

Darmada. 2013. Kontribusi Kompetensi Manajerial Kepala Sekolah, Iklim Kerja Dan Motivasi kerja Terhadap Kinerja Guru SMP Negeri Se-Kecamatan Mendoyo Kabupaten Jembrana. $e$ Journal Program Pascasarjana Universitas Pendidikan Ganesha Jurusan pendidikan Dasar (Volume 3 Tahun 2013).

Ekosiswoyo. 2007. Kepemimpinan Kepala Sekolah yang Efektif Kunci Pencapaian Kualitas Pendidikan. Jurnal Ilmu Pendidikan ISSN 0215 - 9643 dan EISSN : 2442 - 8655 Universitas Negeri Malang.

Hermawan, Arif. 2010. Faktor - Faktor Penghemat Dalam pembelajaran pendidikan. Yokyakarta: FIK UNY

Isjoni. 2009. Pembelajaran Kooperatif Meningkatkan Kecerdasan Komunikasi Antar Guru Maupun Peserta Didik. Yogyakarta: Pustaka Belajar.

Jay, Abwalla. 2014. The Principals Leadership Style And Teachers Performance In Secondary Schools of Gambella Regional State Ethiopia. Journal of Education Jimma University Ethiopia,

Keputusan Menteri Pendidikan Nomor: 162/U/2003 tanggal 24 Oktober 2003 tentang Pedoman Penugasan Guru sebagai Kepala Sekolah,

Lazarus. 1986. Perkembangan Peserta Didik. Bandung: CV Pustaka Setia

Mintzberg, Henry. 2006. Tracking Strategies: Toward A General Theory, Oxford University Press Inc., New York

Majid, Abdul. 2006. Perencanaan Pembelajaran. Bandung: PT Remaja Rosdakarya 
Evaluasi Program Manajerial Kepala Sekolah | Egidius Virgo \& Slameto

Mulyasa, Enco. 2003. Menjadi Kepala Sekolah

Profesional Dalam Konteks

Menyukseskan MBS dan KBK.

Bandung: Remaja Rosdakarya

2007. Standar Kompetensi Dan

Sertifikasi Guru. Bandung: PT Remaja

Rosdakarya

Peraturan Menteri Pendidikan Nasional Republik Indonesia No. 13 Tahun 2007. Tentang Standar Kepala Sekolah/Madrasah. Jakarta: Depdiknas

Safitri, E., \& Djailani, A. R. 2015. Kemampuan Manajerial Kepala Sekolah dalam Meningkatkan Kinerja Guru di MIN Rukoh Banda Aceh. Jurnal Administrasi Pendidikan: Program Pascasarjana Unsyiah, Jakarta: Prestasi Pustakaraya

Sagala, S. 2010. Supervisi Pembelajaran

Dalam Profesi Pendidikan. Bandung: Alfabeta.

Siswanto. 2015. Pengantar Manajemen. Jakarta: Bumi Aksara

Suratman, Anitah. 2010. Kompetensi Manajerial Kepala Sekolah,

Ketersediaan Sarpras, Kapabilitas Mengajar Guru, dan Dukungan Orang Tua< kaitannya dengan Prestasi
Belajar Siswa SMP Negeri di Kota Surabaya. Jurnal Pendidikan dan Pembelajaran Vol 17, No 1 Tahun 2010

Taswir. 2014. Manajerial Kepala Sekolah Dalam Meningkatkan Kinerja Guru pada Sekolah Menengah Kejuruan (SMK) Negeri 2 Sinabang kabupaten Simeulue. Jurnal Ilmiah Didaktika Februari 2014.

Wahjosumidjo. 2001. Kepemimpinan Kepala Sekolah. Jakarta: PT Radja Grafindo Persada.

2005. Kepemimpinan Kepala Sekolah. Jakarta: PT Radja Grafindo Persada. 2013. Kepemimpinan Kepala Sekolah, Tinjauan Teoritik dan Permasalahannya. Jakarta: PT Radja Grafindo Persada.

Wirawan. 2011. Evaluasi (Teori, Model, Standar, Aplikasi, dan Profesi). Jakarta: Rajagrafindo Persada.

Zulkarnaen. 2016. Kompetensi Manajerial Kepala Sekolah dalam Meningkatkan Kinerja Guru di SMP Islam Terpadu Kabupaten Aceh. Jurnal Pendidikan ETD Unsyiah Kuala. 